\title{
Persepsi Pemustaka Terhadap Kualitas Layanan Window Of The World (WOW) Perpustakaan UGM Berdasarkan Model Libqual $^{+\mathrm{TM}}$
}

\author{
Tri Andika Oktaviela* \\ email: vielajogja@gmail.com
}

\begin{abstract}
This study aims to find out users' perceptions towards quality of Window of the World (WOW) service based on the LibQUAL ${ }^{+T M}$ models in the library of Universitas Gadjah Mada Yogyakarta. The type of the study is descriptive quantitative. Subjects of the study were users of the facilities of WOW service, while the object of the study was users' perception about the quality of WOW service. Data were obtained from questionnaires, observation, interviews, and documentation. Sampling used incidental sampling technique, with a sample size of 100 respondents. There was a single variable, i.e. perception about WOW service. Data analysis used the mean and grand mean. Measurement of users' perception was based on the Libqual ${ }^{+T M}$ models that included four dimensions. These were ability and attitude of librarians in serving (Service Affect-SA), the dimensions of the facilities and atmosphere of the space of the library (Library As Place-LP), the dimensions of the user and means of access (Personal Control$P C$ ), and the dimensions of information access (information access-IA). Each dimension showed that the perception of the dimension of librarian in serving (Service Affact-SA) with an average of 3.05 (good), the dimensions of the facilities and atmosphere of the space of the library (Library As Place-LP) with an average of 3.13 (good), the dimensional directions and means of access (Personal Control-PC) with an average of 3.12 (good), and the dimensions of information access (information access-IA) with an average of 3.06 (good). The result showed that the users' perception about WOW service based on LibQUAL ${ }^{+T M}$ models in library of Universitas Gadjah Mada Yogyakarta was good. It can be seen from the total average of variable that is equal to 3.09, so it is necessary to improve the quality of WOW service in the library of Universitas Gadjah Mada Yogyakarta to achieve excellent category. It was especially necessary to improve quality at its lowest dimensions on the dimensions of librarians in serving (Service Affect $-S A$ ) with an average of 3.05 .
\end{abstract}

Keywords: User, Perception, Quality of Service, Window of the World Service

*) Mahasiswa UIN Sunan Kalijaga Yogyakarta

A. PENDAHULUAN

1. Latar Belakang

Santoso (2010: 478) mengatakan bahwa era globalisasi dapat membawa dampak negatif bagi masyarakat. Dampak tersebut dapat berpotensi menurunkan nilai luhur bangsa khususnya generasi bangsa. Era globalisasi juga akan berdampak pada berbagai aspek kehidupan masyarakat, seperti timbulnya krisis kebudayaan yang dapat menyebabkan krisis sosial, krisis ekonomi, krisis psikologi, dan berbagai jenis krisis lainnya.

Suwarno (2011: 19) mengatakan bahwa salah satu dari misi perpustakaan yaitu meningkatkan kesadaran terhadap budaya, apresiasi seni, dan hasil temuan ilmiah. Dari pendapat tersebut, maka salah satu tugas perpustakaan yaitu sebagai tempat pengumpulan bahan pustaka yang merupakan hasil budi daya manusia baik nasional maupun internasional. Pentingnya nilai-nilai budaya nasional dan budaya internasional sangat dibutuhkan dalam membentuk pribadi seseorang. Salah satu perpustakaan yang dapat mendukung terlaksananya fungsi perpustakaan di atas yaitu perpustakaan perguruan tinggi.

Sulistyo-Basuki (2010:2.17) mengatakan bahwa perpustakaan perguruan tinggi adalah 
perpustakaan yang berada pada lingkungan perguruan tinggi, badan bawahannya maupun lembaga yang berafiliasi dengan perguruan tinggi dengan tujuan utama membantu perguruan tinggi mencapai tujuannya yaitu pendidikan, penelitian, dan pengabdian. Dalam mewujudkan suatu tujuan tersebut maka perpustakaan harus terus menerus berinovasi, yaitu dengan mengembangkan layanan perpustakaan. Sebagaimana tertulis dalam UU RI Nomor 43 Tahun 2007 tentang perpustakaan pada Bab V pasal 16 mengenai layanan perpustakaan bahwa layanan perpustakaan harus dikembangkan sesuai dengan kemajuan teknologi informasi dan komunikasi. Sesuai penjelasan di atas maka perpustakaan harus berinovasi dalam mengembangkan layanan yang ada di perpustakaan. Dalam meningkatkan kualitas dan memberikan layanan yang inovatif, maka Perpustakaan UGM berinovasi dengan membuka layanan window of the world (WOW).

Berdasarkan hasil wawancara pada hari Kamis tanggal 10 September 2015 pukul 08.30 WIB dengan Ibu Lilik Kurniawati Uswah, SE., M.Si selaku pustakawan di layanan WOW mengatakan bahwa awal berdirinya layanan WOW bermula dari ide Rektor UGM yaitu Bapak Prof. Dr. Pratikno M. Soc. Sc., menggagas untuk membuat konsep layanan perpustakaan sesuai dengan slogan UGM yaitu "mengakar kuat menjulang tinggi" yang selama ini tetap melekat di UGM. Slogan ini sebagai dasar UGM untuk melahirkan generasi muda yang berjaya dan bersahaja serta berkelas dunia. Dalam berita harian di website UGM, menurut Purwanti (2014) untuk mendukung visi UGM sebagai perguruan tinggi nasional berkelas dunia tersebut, maka Perpustakaan UGM terus berupaya menyediakan beragam referensi buku yang dapat menunjang kegiatan pembelajaran dan penelitian. Layanan WOW diharapkan dapat menjadi jendela bagi segenap sivitas akademika untuk mempelajari bangsa-bangsa lain di dunia, mengakses informasi terkait budaya, nilai, dan seluruh informasi dari Indonesia dan belahan dunia lainnya.

Untuk mengetahui informasi yang didapat dari pemustaka berdasarkan pengalamannya memanfaatkan layanan WOW, peneliti melakukan wawancara terkait layanan WOW. Wawancara dilakukan dengan salah satu pemustaka yang memanfaatkan layanan yaitu
Novi Puspita pada hari Sabtu tanggal 9 Januari 2016 pukul 10.30 WIB. Pemustaka tersebut menuturkan sering mengunjungi layanan WOW karena ruangan sangat nyaman dan koleksi yang disediakan menarik untuk dibaca, akan tetapi pemustaka tersebut menuturkan agar layanan WOW menambah koleksi dalam bentuk buku bacaan tercetak dan menambah petunjuk tertulis. Berdasarkan pemaparan pemustaka tersebut dapat diketahui bahwa masih terdapat indikator dari model LibQual ${ }^{+\mathrm{TM}}$ yang belum terpenuhi yaitu pada permasalahan koleksi dalam bentuk buku tercetak yang masih terbatas yaitu termasuk pada dimensi akses informasi (Information Access-IA) pada sub variabel Isi/Ruang lingkup (Conten/Scope) dan kurangnya petunjuk tertulis untuk memanfaatkan layanan WOW yaitu termasuk pada dimensi petunjuk dan sarana akses (Personal Control-PC) pada sub variabel kenyamanan individu pemustaka (convenience). Berdasarkan penjelasan di atas, diperoleh data sementara bahwa masih terdapat indikator berdasarkan model $\mathrm{LibQUAL}^{+\mathrm{TM}}$ pada layanan WOW yang dirasa masih kurang memenuhi kebutuhan pemustaka.

Meskipun Perpustakaan UGM sudah berupaya semaksimal mungkin untuk mempertahankan kualitas layanan WOW, akan tetapi berdasarkan hasil wawancara dengan pemustaka di atas masih terdapat beberapa hal yang di rasa masih belum terpenuhi dengan yang pemustaka rasakan di layanan WOW. Pada penelitian ini, peneliti menggunakan metode LibQUAL $^{+{ }^{+M}}$ untuk mengukur lebih lanjut kualitas layanan WOW berdasarkan persepsi pemustaka.

\section{Rumusan Masalah}

Berdasarkan latar belakang di atas, maka rumusan masalah dalam penelitian ini yaitu bagaimana persepsi pemustaka terhadap kualitas layanan WOW berdasarkan model LibQUAL $^{+\mathrm{TM}}$ di Perpustakaan UGM?

\section{Tujuan dan Manfaat}

Penelitian ini bertujuan untuk mengetahui persepsi pemustaka terhadap kualitas layanan WOW berdasarkan model LibQUAL ${ }^{\mathrm{TM}}$ di Perpustakaan UGM.

Sedang manfaat penelitian ini adalah sebagai bahan masukan bagi manajemen 
Perpustakaan UGM untuk meningkatkan mutu layanan WOW, untuk memperoleh ilmu pengetahuan dan wawasan dalam pengembangan perpustakaan, dan sebagai bahan referensi dalam pengembangan penelitian selanjutnya.

\section{B. TINJAUAN PUSTAKA DAN LANDASAN TEORI}

\section{Tinjauan Pustaka}

Berdasarkan hasil penelusuran yang peneliti lakukan terhadap beberapa penelitian yang sejenis, peneliti menemukan beberapa penelitian yang selanjutnya akan digunakan sebagai acuan, berikut ini:

Penelitian pertama dilakukan oleh Utami (2013) yang berjudul "Persepsi Mahasiswa Tentang Kualitas Pelayanan Perpustakaan Berdasarkan Model LibQUAL di Direktorat Perpustakaan Universitas Islam Indonesia”. . Hasil penelitian yang diperoleh skor kriteria berdasarkan rata-rata secara keseluruhan didapat hasil 3,24, sehingga dapat dikategorikan bahwa kualitas pelayanan pada Direktorat Perpustakaan Universitas Islam Indonesia tergolong baik. Penelitian kedua dilakukan oleh Rahma Setiani (2014) yang berjudul "Evaluasi Kualitas Pelayanan Perpustakaan Daarul Ilmi SMP IT Abu Bakar Yogyakarta Dengan Metode LibQUAL $^{\text {TM }}$ Berdasarkan Harapan Dan Persepsi Pemustaka". Kualitas perpustakaan sudah dinilai baik, akan tetapi belum unggul (superior). Perlu dilakukan pengembangan dan perbaikan terkait sikap pustakawan dalam melayani, dan mengadakan bimbingan pemustaka. Penelitian ketiga dilakukan oleh Haryani (2014) yang berjudul "Evaluasi Kualitas Layanan Malam Hari di Kantor Arsip dan Perpustakaan Kota Yogyakarta dengan Metode LibQUAL ${ }^{+\mathrm{TM}}$,. Hasil Penelitian ini menunjukkan bahwa kualitas layanan malam hari di Kantor Arsip dan Perpustakaan Kota Yogyakarta dinyatakan "baik" secara umum oleh pemustaka.

\section{Landasan Teori}

\section{a. Definisi Persepsi}

Menurut Poerwadarminta (2011:880) dalam Kamus Umum Bahasa Indonesia persepsi dapat diartikan sebagai tanggapan, proses seseorang mengetahui beberapa hal melalui penginderaannya. Namun dalam psikologi, persepsi mempunyai pengertian yang lebih luas. Menurut Walgito (2004:87-88) persepsi merupakan suatu proses yang didahului oleh proses penginderaan, yaitu merupakan proses diterimanya stimulus oleh individu melalui alat indera atau juga disebut proses sensoris.

\section{b. Definisi Pemustaka}

Menurut Lasa (2009:237) pemustaka (user) adalah orang, sekelompok orang, atau lembaga yang memanfaatkan fasilitas atau layanan suatu perpustakaan. Pendapat yang hampir senada dijelaskan dalan Undang-Undang Nomor 43 tahun 2007 pasal 1 ayat 9 bahwa pengguna perpustakaan, yaitu perseorangan kelompok orang, masyarakat, atau lembaga yang memanfaatkan fasilitas layanan perpustakaan.

\section{c. Perpustakaan Perguruan Tinggi}

Menurut Purwono (2013:18) bahwa perpustakaan perguruan tinggi merupakan unit pelaksana teknis (UPT) perguruan tinggi yang bersama-sama dengan unit lain turut melaksanakan Tridarma Perguruan Tinggi dengan cara menghimpun, mengolah, merawat, serta melayangkan sumber informasi kepada lembaga industri khususnya dan masyarakat akademis pada umumnya. Sedangkan menurut Saleh dan Rita (2011: 1.17) perpustakaan perguruan tinggi adalah perpustakaan yang berada di lingkungan perguruan tinggi, universitas, sekolah tinggi, akademi dan pendidikan tinggi lainnya, yang pada hakikatnya merupakan bagian integral dari suatu perguruan tingginya.

\section{d. Definisi Kualitas Layanan}

Menurut Poerwadarminta (2011: 621) kualitas berarti: (1) mutu; (2) tingkat baik buruk (suatu benda). Menurut Tjiptono dan Anastasia (2003:3) kualitas merupakan suatu kondisi dinamis yang berhubungan dengan produk, jasa, manusia, proses, dan lingkungan yang memenuhi atau melebihi harapan pelanggan. 


\section{e. Dimensi LibQUAL ${ }^{+T M}$}

Menurut Fatmawati (2014: 217-225) mengatakann bahwa metode LIbQUAL ${ }^{+T M}$ merupakan metode pengembangan dari metode SERVQUAL, akan tetapi metode LibQUAL $^{+\mathrm{TM}}$ merupakan metode khusus yang digunakan sebagai tolak ukur dalam riset kualitas layanan perpustakaan. Dalam Pengukuran dimensi LibQUAL ${ }^{+\mathrm{TM}}$ terdapat empat dimensi menurut Fatmawati (2014: 217-225), yaitu:

1. Kemampuan dan Sikap Pustakawan Dalam Melayani (Service Affect-SA) yaitu kemampuan, sikap dan mentalitas pustakawan dalam melayani pemustaka.

2. Fasilitas dan Suasana Ruang Perpustakaan (Library as Place-LP) yaitu Konsep yang digunakan untuk menilai kemampuan perpustakaan dalam memenuhi harapan pemustaka dalam penyediaan berbagai fasilitas perpustakaan.

3. Petunjuk dan Sarana Akses (Personal Control-PC) yaitu Konsep yang digunakan untuk menilai kemampuan perpustakaan dalam memenuhi harapan pemustaka dengan adanya petunjuk dan sarana akses perpustakaan.

4. Akses Informasi (Information Access$I A$ ) yaitu konsep menyangkut tentang ketersediaan bahan perpustakaan yang memadai, kekuatan koleksi bahan pustaka yang dimiliki, cakupan isi/ruang lingkup, aktualitas, bimbingan pusta-kawan, maupun tingkat kecepatan waktu akses informasi di perpustakaan.

\section{f. Layanan WOW}

Menurut Uswah (2014:142) layanan WOW merupakan layanan yang dirancang dengan menjadikan perpustakaan sebagai jendela yang terhubung dengan pusat akses lain yaitu rumah budaya dan rumah internasional, pusat-pusat studi berbasis kewilayahan, organisasi mahasiswa, dan mitra lain internal dan eksternal UGM.

\section{METODE PENELITIAN}

Penelitian ini menggunakan metode deskriptif karena yaitu menjelaskan atau mendeskripsikan fenomena yang diteliti. Pendekatan yang digunakan adalah dengan metode kuantitatif. Penelitian ini dilaksanakan di Perpustakaan UGM pada bulan FebruariMaret 2016.

1. Subjek dan Objek Penelitian

Subyek dalam penelitian ini yaitu pemustaka yang memanfaatkan layanan (WOW) di Perpustakaan UGM. Sedangkan objek dalam penelitian ini adalah hal yang diteliti sesuai dengan rumusan masalah yaitu mengenai persepsi pemustaka terhadap kualitas layanan (WOW) di Perpustakaan UGM.

2. Populasi dan Sampel

Populasi dalam penelitian ini berjumlah 32.922 pemustaka yang berasal dari data statistik layanan WOW tahun 2015. Teknik pengambilan sampel yang digunakan dalam penelitian ini adalah motode incidental sampling. Menurut Sugiyono (2014:85) motode incidental sampling yaitu teknik penentuan sampel berdasarkan kebetulan, yaitu siapa saja yang secara kebetulan atau insidental bertemu dengan peneliti dapat digunakan sebagai sampel, bila dipandang orang yang kebetulan ditemui itu cocok sebagai sumber data.

3. Metode Pengumpulan Data

Adapun teknik pengumpulan data yang digunakan dalam penelitian ini yaitu observasi, dokumentasi, wawancara, dan kuesioner.

\section{Observasi}

Menurut Riduwan (2013:57) observasi dilakukan dengan melakukan pengamatan secara langsung ke obyek penelitian untuk melihat dari dekat kegiatan yang dilakukan Dalam penelitian ini, pengamatan dilakukan di layanan WOW. Hal tersebut dimaksudkan agar peneliti dapat mendapatkan informasi atau data yang lengkap dan utuh dari obyek yang diteliti. 


\section{Dokumentasi}

Arikunto (2006:158) men-jelaskan bahwa dokumentasi berasal dari kata dokumen yang artinya barang-barang tertulis. Dalam pengertian yang lebih luas, dokumen bukan hanya yang berwujud tulisan saja, tetapi dapat berupa bendabenda peninggalan seperti prasasti dan simbol-simbol. Peneliti menggunakan metode dokumentasi karena peneliti ingin mendapatkan informasi mendalam tentang berbagai permasalahan yang ada pada obyek penelitian dalam bentuk tulisan dan gambar.

\section{Wawancara}

Dalam penelitian ini, peneliti menggunakan wawancara tidak terstruktur. Menurut Sugiyono (2014:140) wawancara tidak terstruktur yaitu wawancara yang bebas dimana peneliti tidak menggunakan pedoman wawancara yang telah tersusun secara sistematis dan lengkap untuk pengumpulan datanya. Pemilihan metode tersebut karena peneliti ingin mendapatkan informasi mendalam tentang berbagai permasalahan yang ada pada obyek penelitian.

\section{Kuesioner (Angket)}

Menurut Sugiyono (2014: 142) kuesioner merupakan teknik pengumpulan data yang dilakukan dengan cara memberi seperangkat pertanyaan atau pernyataan tertulis kepada responden untuk di jawabnya. Dalam penelitian ini, peneliti memberikan secara langsung kepada subyek penelitian yaitu pemustaka di layanan window of the world (WOW).

\section{Instrumen Penelitian}

Menurut Sugiyono (2014: 102) menjelaskan bahwa pada prinsipnya penelitian adalah melakukan pengukuran terhadap fenomena sosial maupun alam, instrumen penelitian adalah suatu alat yang digunakan dalam mengukur fenomena sosian dan alam yang diamati secara spesifik semua fenomena ini disebut variabel penelitian. Instrumen yang digunakan dalam penelitian ini berdasarkan pada uraian yang ada pada landasan teori menurut Endang Fatmawati (2014) yang terdiri dari 4 (empat) sub variabel yaitu: (1) Kemampuan dan Sikap Pustakawan Dalam Melayani (Service Affect-SA), (2) Fasilitas dan Suasana Ruang Perpustakaan (Library as PlaceLP), (3) Petunjuk dan Sarana Akses (Personal Control-PC), dan (4) Akses Informasi (Information Access-IA).

\section{Analisis Data}

Analisis data yang digunakan yaitu mean dan grand mean. Mean digunakan untuk mengetahui atau menghitung ratarata dengan menggunakan perhitungan aritmatika. Sedangkan grandmean digunakan untuk menghitung nilai rata-rata total, Rumus mean menurut Sudjiono (2011: 81) adalah sebagi berikut:

$$
\text { Mean }=X=\frac{\Sigma x}{N}
$$

Keterangan:

$X=$ rata-rata hitung

$\sum x=$ jumlah semua nilai kuesioner

$N=$ jumlah responden

Sedangkan rumus Grandmean sebagai berikut:

Grand Mean $(x)=\frac{\text { total rata }- \text { rata hitung }}{\text { jumlah pertanyaan }}$

Dalam penelitian ini, untuk mengukur persepsi layanan dapat dikelompokkan ke dalam skala interval.

Tabel 1. Kategori berdasarkan skor rata-rata MX

\begin{tabular}{l|c}
\hline \multicolumn{1}{c|}{ Kategori } & Skor \\
\hline Sangat Tidak Baik & $1,0-1,75$ \\
Tidak Baik & $>1,75-2,50$ \\
Baik & $>2,50-3,25$ \\
Sangat Baik & $>3,25-4,00$ \\
\hline \multicolumn{2}{c}{ Sumber: Mustafa (2009:150) }
\end{tabular}




\section{HASIL DAN PEMBAHASAN}

1. Dimensi Kemampuan dan Sikap Pustakawan Dalam Melayani (Service AffectSA)

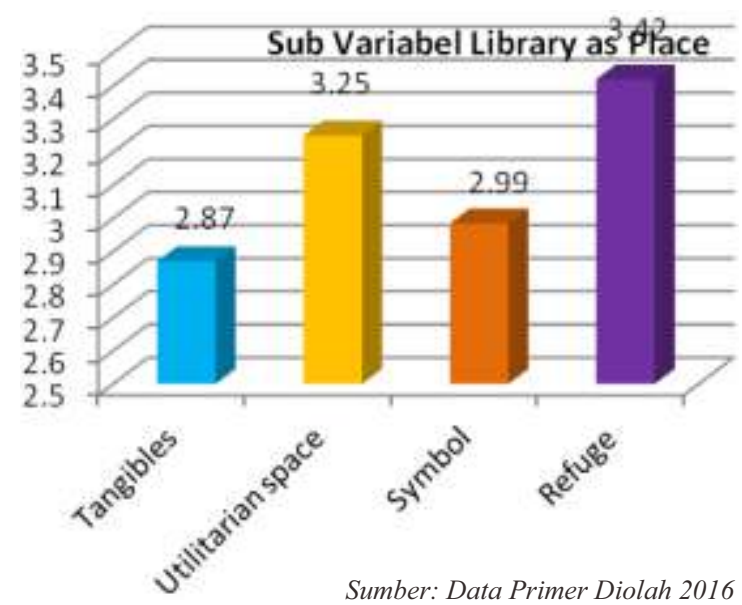

Grafik 1. Persepsi Mahasiswa Pada Sub Variabel Service Affect (SA)

Berdasarkan Grafik 1 dapat diketahui persepsi pemustaka tentang kualitas pelayanan mengenai dimensi kemampuan dan sikap pustakawan dalam melayani (Service AffectSA) yang meliputi empathy dengan rata-rata sebesar 2,93, responsiveness dengan rata-rata sebesar 3,13, assurance dengan rata-rata sebesar 3,11, dan reliability dengan rata-rata sebesar 3,03, sehingga dapat dianalisis bahwa persepsi pemustaka dari dimensi kemampuan dan sikap pustakawan dalam melayani (Service Affect-SA) diperoleh grandmean sebesar 3.05 yaitu dikategorikan baik.

2. Dimensi Fasilitas Dan Suasana Ruang Perpustakaan (Library As Place-LP)

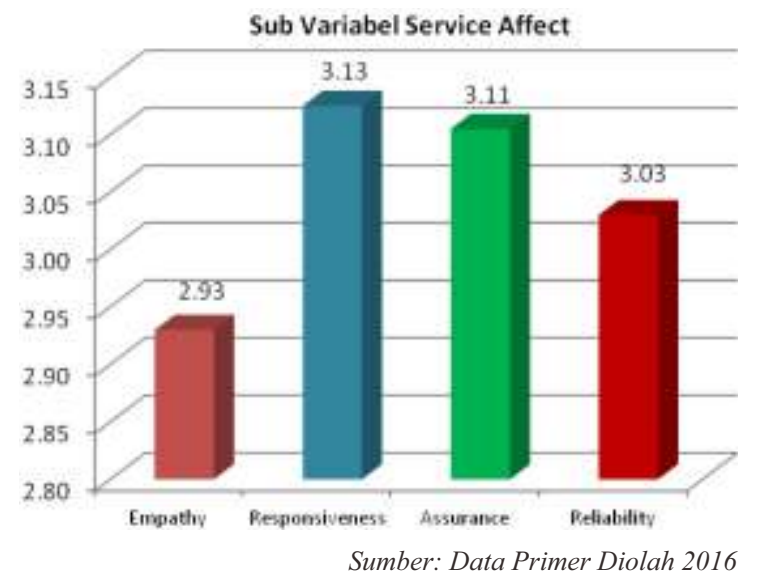

Grafik 2. Persepsi Pemustaka Pada Sub Variabel Library as Place (LP)
Berdasarkan Grafik 2 dapat diketahui persepsi pemustaka tentang kualitas pelayanan mengenai dimensi fasilitas dan suasana ruang perpustakaan (Library As Place-LP) yang meliputi tangibles dengan rata-rata sebesar 2,87 , utilitarian space dengan rata-rata sebesar 3,25 , symbol dengan rata-rata sebesar 2,99, dan refuge dengan rata-rata sebesar 3,42, sehingga dapat dianalisis bahwa persepsi pemustaka dari dimensi fasilitas dan suasana ruang perpustakaan (Library As Place-LP) diperoleh grandmean sebesar $\mathbf{3 . 1 3}$ yaitu dikategorikan baik.

1. Dimensi Petunjuk dan Sarana Akses (Personal Control-PC)

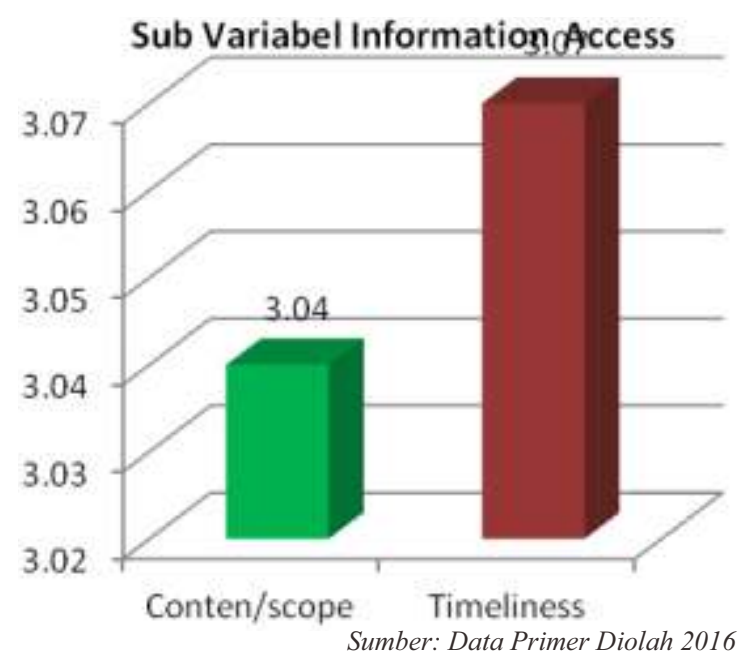

Grafik 3. Persepsi Pemustaka Pada Sub Variabel Personal Control (PC)

Berdasarkan Grafik 3 dapat diketahui persepsi pemustaka tentang kualitas pelayanan mengenai dimensi petunjuk dan sarana akses (Personal Control-PC) yang meliputi ease of navigation dengan rata-rata sebesar 3,05 , convenience dengan rata-rata sebesar 2,97 , modern equipment dengan rata-rata sebesar 3,24 , dan self reliance dengan rata-rata sebesar 3,24 , sehingga dapat dianalisis bahwa persepsi pemustaka dari dimensi petunjuk dan sarana akses (Personal Control-PC) diperoleh grandmean sebesar $\mathbf{3 . 1 2}$ yaitu dikategorikan baik. 


\section{Dimensi Akses Informasi (Information Access-IA)}

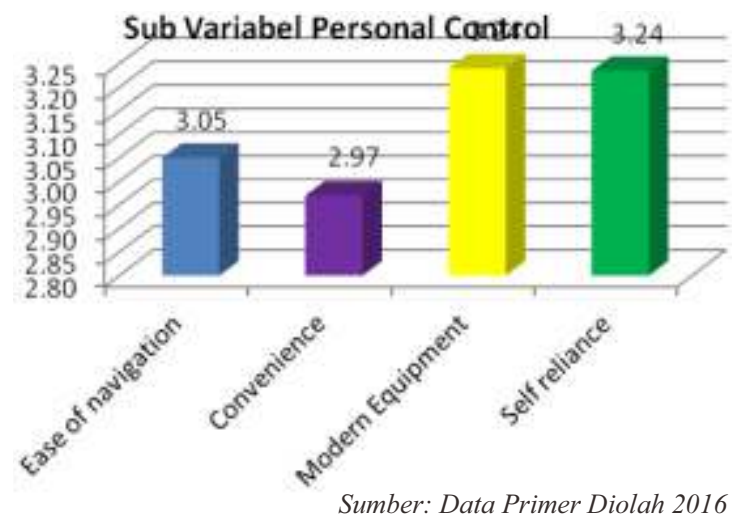

Grafik 4. Persepsi Pemustaka Pada Sub Variabel Information Access (IA)

Berdasarkan Grafik 4 dapat diketahui persepsi pemustaka tentang kualitas pelayanan mengenai dimensi akses informasi (Information Access-IA) yang meliputi content/scope dengan rata-rata sebesar 3,04, timeliness dengan ratarata sebesar 3,07, sehingga dapat dianalisis bahwa persepsi pemustaka dari dimensi akses informasi (Information Access-IA) diperoleh grandmean sebesar 3.06 yaitu dikategorikan baik.

\section{KESIMPULAN}

Berdasarkan perolehan analisis data dan pembahasan pada kegiatan penelitian persepsi pemustaka terhadap kualitas layanan window of the world (WOW) berdasarkan model LibQUAL ${ }^{+\mathrm{TM}}$ di Perpustakaan UGM Yogyakarta diperoleh total nilai rata-rata persepsi pemustaka sebesar $\mathbf{3 . 0 9}$ yang berarti dikategorikan baik. Hasil analisis persepsi pemustaka dari keempat dimensi yang memiliki nilai rata-rata terendah dari masing-masing dimensi tersebut yaitu sebagi berikut:

1. Dimensi Service Affect-SA yaitu pada indikator empathy, pada pernyataan pustakawan memberikan perhatian yang sungguh-sungguh kepada pemustaka.

2. Dimensi Library As Place-LP yaitu pada indikator tangibles, pada pernyataan ketersediaan buku bacaan di layanan WOW mencukupi dengan kebutuhan pemustaka.

3. Dimensi Personal Control-PC yaitu pada indikator convenience, pada pernyataan kejelasan petunjuk yang dapat memudahkan pemustaka untuk memanfaatkan fasilitas dan koleksi di layanan WOW.

4. Dimensi Information Access-IA yaitu pada indikator conten/scope, pada pernyataan dalam hal ketersediaan buku atau koleksi dalam bentuk budaya Indonesia dan berbagai negara lain sudah mencukupi yang pemustaka butuhkan.

\section{DAFTAR PUSTAKA}

Arikunto, Suharsimi. 2006. Prosedur Penelitian: Suatu Pendekatan Praktik. Jakarta: Rineka Cipta.

Fatmawati, Endang. 2014. Matabaru Penelitian Perpustakaan: dari SerQUAL ke LibQUAL. Jakarta: Sagung Seto.

Haryani. 2014. Evaluasi Kualitas Layanan Malam Hari Di Kantor Arsip dan Perpustakaan Kota Yogyakarta Dengan Metode LIBQUAL ${ }^{+T M}$. Yogyakarta:Universitas Islam Negeri Sunan Kalijaga.

Lasa Hs. 2009. Kamus Kepustakawanan Indonesia. Yogyakarta : Pustaka Book Publisher.

Poerwadarminta, W,J.S. 2011. Kamus Umum Bahasa Indonesia. Jakarta: Balai Pustaka.

Purwanti, Nawang. 2014. Perpustakaan UGM Kembangkan Layanan Windows Of The World. Yogyakarta. Dalam https://ugm.ac.id/id/ berita/9046-perpustakaan.ugm.kembangkan .layanan.windows.of.the.world. Diakses pada 12 Januari 2016 pukul 08.02 WIB.

Purwono. 2013. Profesi Pustakawan Menghadapi Tantangan Perubahan. Yogyakarta: Graha Ilmu.

Riduwan. 2013. Dasar-Dasar Statistika. Bandung: Alfabeta.

Saleh, Abdul Rahman dan Rita Komalasari. 2011. Manajemen Perpustakaan. Jakarta: Universitas Terbuka.

Santoso, Agus Muji. 2010. Konsep Diri Melalui Pendidikan Berbasis Keunggulan Lokal Sebagai Model Pendidikan Berkarakter dan Berbudaya Bangsa Di Era Global. Dalam Procedings of the 4th International Conference On Teacher Education, Join Conference UPI \& UPSI. Bandung, 8-10 November 2010. 
Setiani, Rahma. 2014. Evaluasi Kualitas Pelayanan Perpustakaan Daarul Ilmi SMP IT Abu Bakar Yogyakarta Dengan Metode LIBQUAL ${ }^{+T M}$ Berdasarkan Harapan dan Persepsi Pemustaka. Yogyakarta: Universitas Islam Negeri Sunan Kalijaga.

Sudjiono, Anas. 2011. Pengantar Statistik Pendidikan. Jakarta: Rajawali Pers.

Sugiyono. 2014. Metode Penelitian Kuantitatif, KualitatifDan R\&D. Bandung: Alfabeta.

Sulistyo-Basuki. 2010. Pengantar Ilmu Perpustakaan. Jakarta: Universitas Terbuka.

Suwarno, Wiji. 2011. Perpustakaan dan Buku: Wacana Penulisan dan Penerbitan. Yogyakarta: Ar-Ruzz Media.

Tjiptono, Fandy dan Anastasia Diana. 2003. Service, Quality, \& Satisfaction. Yogyakarta: Andi.
Undang-undang Republik Indonesia Nomor 43 tahun 2007 tentang Perpustakaan. Jakarta: Perpustakaan Nasional RI.

Uswah, Lilik Kurniawati. 2014. Indonesia Indigeneous Resources Center (IRC) Di Perpustakaan Universitas Gadjah Mada: Sajian Lokal Bagi Generasi Global. Dalam Palimpest, Tahun VI Nomor 2, Desember 2014Mei 2015.

Utami, Anggita Marga. 2013. Persepsi Mahasiswa Tentang Kualitas Pelayanan Perpustakaan Berdasarkan Model LIBQUAL di Direktorat Perpustakaan Universitas Isam Indonesia. Yogyakarta: Universitas Islam Negeri Sunan Kalijaga.

Walgito, Bimo. 2004. Pengantar Psikologi Umum. Yogyakarta: Andi. 